Article

\title{
Tipping to Staying on the Ground: Internalized Knowledge of Climate Change Crucial for Transformed Air Travel Behavior
}

\author{
Lisa Jacobson ${ }^{1, *(\mathbb{D})}$, Jonas Åkerman ${ }^{2}$, Matteo Giusti ${ }^{3}$ and Avit K. Bhowmik ${ }^{4}$ (D) \\ 1 Stockholm Resilience Centre, Stockholm University, 10405 Stockholm, Sweden \\ 2 Department of Sustainable Development, Environmental Science and Engineering, Royal Institute of \\ Technology, KTH, 10044 Stockholm, Sweden; jonas.akerman@abe.kth.se \\ 3 Department of Building Engineering, Energy Systems and Sustainability Science, University of Gävle, \\ 80176 Gävle, Sweden; matteo.giusti@hig.se \\ 4 Risk and Environmental Studies, Karlstad University, 65188 Karlstad, Sweden; avit.bhowmik@kau.se \\ * Correspondence: lisa.jacobson@futureearth.org; Tel.: +46-707-702-147
}

Received: 16 January 2020; Accepted: 2 March 2020; Published: 5 March 2020

\begin{abstract}
Air travel accounts for a major share of individual greenhouse gas emissions, particularly for people in high-income countries. Until recently, few have reduced flying because of climate concerns, but currently, a movement for staying on the ground is rising. Sweden has been a focal point for this movement, particularly during 2018-2019, when a flight tax was introduced, and air travel reduction was intensely discussed in the media. We performed semi-structured interviews with Swedish residents, focusing primarily on individuals who have reduced flying because of its climate impact. We explore how such individual transformation of air travel behavior comes about, and the phases and components of this process. Applying a framework of sustainability transformation, we identify incentives and barriers in personal and political spheres. We show that internalized knowledge about climate change and the impact of air travel is crucial for instigating behavioral change. Awareness evokes negative emotions leading to a personal tipping point where a decision to reduce or quit flying is made. However, the process is often counteracted by both personal values and political structures promoting air travel. Even individuals with a strong drive to reduce flying feel trapped in social practices, norms and infrastructures. Hence, we argue that personal and political spheres interact complexly and to reduce flying at larger scales, interventions are needed across spheres, e.g., change of norms, effective policy instruments and better alternatives to air travel.
\end{abstract}

Keywords: air travel; behavioral change; climate change; sustainability; transformation

\section{Introduction}

The Paris Climate Agreement [1] and related efforts (e.g., recent IPCC reports) call for radical action to limit global warming to $1.5{ }^{\circ} \mathrm{C}[2,3]$. The window of opportunity to meet this goal is rapidly closing, and hence, efficient mitigation strategies are urgently needed [4,5]. Although existing top-down policies predominantly focus on technical solutions, disruptive transformations spanning across individual mindsets, social norms and political structures are imperative for successful climate action and sustainability transformation [6-9].

Air travel accounts for $4-5 \%$ of the global anthropogenic climate impact, taking into account both $\mathrm{CO} 2$ and other emissions at high altitudes [10-12]. This might seem marginal, but only a small portion of the global population is responsible for these emissions. In 2007, only $2 \%$ were estimated to take an international flight [13], and recently, general media has reported 5-10\% [14]. Moreover, in high-income countries, air travel's share of greenhouse gas (GHG) emissions greatly exceeds the global average [15]. 
Since the aviation sector is growing rapidly globally-it has been projected to nearly quadruple between 2005 and 2050 - improved aircraft and fuels will not be enough to bend the curve of increasing air travel-related emissions [15-18]. To reduce the climate impact of flying, behavioral change, coupled with political and infrastructural transformations, is thus instrumental $[19,20]$.

\subsection{Climate Action and Air Travel}

For people who fly, reducing air travel is one of the most efficient ways to cut individual GHG emissions. Avoiding one transatlantic round trip saves about 1.6 tons of $\mathrm{CO}_{2}$ equivalents [21], which is comparable to the entire annual sustainable carbon budget (1.5-2 tons) per person [22-24].

According to economic theory, environmental awareness reduces the willingness to pay for polluting goods and services $[25,26]$. However, in the case of air travel, previous studies show that few choose to limit flying because of climate concerns [27-29]. Climate inaction is not subject primarily to individuals' lack of knowledge (information deficit model) but also to an intricate interplay between values, beliefs and norms [30-32]. The gap between knowledge and action, attitudes and behavior, is well documented [33-35].

Gifford has described the psychological barriers to efficient GHG mitigation as "dragons of inaction" [36] related to, for example, cognition, ideology, comparisons with others and perceived risks of change. Many perceive climate change (CC) as distant in time and space, and according to Weber, it seldom elicits "visceral reactions", such as dread [37]. On the other hand, Stoknes and others argue that CC portrayed in doomsday scenarios may create denial as it is perceived as a threat to identity and lifestyle [32,38]. This is not primarily a denial of climate science, but a deeply emotional and socially organized denial, as described by Norgaard. Although some have the knowledge and do care about CC, many keep the topic disconnected from political, social and private life as it triggers emotions too difficult to handle [39].

Individuals' behavior depends both on attitudes and contextual factors, such as available alternatives and economic and political incentives [40]. The harder, more expensive and time-consuming a pro-environmental behavior is to carry out, the weaker the influence of attitudes becomes [30].

Several earlier studies have shown that the gap between attitudes and behavior is particularly large when it comes to air travel [41,42]. Even people feeling guilt connected to flying have not been strongly motivated to reduce [43]. This has been explained with cognitive dissonance theory, suggesting that the unease felt by individuals when they act against their pro-environmental values is more commonly solved by adjusting attitudes than behavior. The majority thus find various justifications for their flights instead of reducing flying [28], and many tend to "take a break" from environmental concerns during holidays [41].

Cheaper flights have made it possible for many to travel extensively for both professional and private reasons [44]. Since flying has become the norm and part of social practices, global connectedness and a defining dimension of social status, the habit is hard to break-frequent flying has even been portrayed as an addiction $[45,46]$.

By contrast, some individuals indeed manage to reduce flying to minimize their contribution to CC. These individuals have been shown to have a strong sense of responsibility for CC, feel a moral obligation to mitigate it and distance themselves from dominant social norms [42].

\subsection{The Rising Fly-Less Movement in Sweden}

In this study, we focus on Swedish flying habits-which provide an intriguing illustration of the gap between environmental attitudes and behavior. Sweden was one of the first nations in the world to introduce a carbon tax, but the consumption-based GHG emissions are still high, around 9 tons per person and year [47]. Most Swedes are worried about CC and aware that aviation is contributing to the problem [48-50] However, Swedes typically fly five times more than the global average [51] and international air travel accounts for approximately $10 \%$ of Swedish consumption-based emissions [52]. 
A movement to reduce flying has taken off in Sweden in recent years. During 2017, a proposed tax on air travel was debated, and sporadic opinion pieces were published in the media advocating for air travel reduction. In early 2018, the general interest increased dramatically when a few influential journalists wrote about their personal decisions to stop flying because of CC [53-55]. A vivid debate about individual responsibility and air travel exploded and spread across mainstream and social media. The word "flygskam", "flight shame" in English, was established and spread internationally [56,57].

In the fall of 2018, the teenage climate activist Greta Thunberg sparked the global student movement "Fridays For Future". Thunberg's international impact and her advocating for sustainable traveling have helped spread the antiflight movement further. In 2019, Swedish air traveling declined for the first time ever [58].

\subsection{Aims of This Study}

Previous research on environmentally significant behavior has often focused on individuals' values, beliefs and norms [30,42], while other scholars have pointed to contextual factors and social practices as more influential than the free choice of individuals $[40,59]$. The aim of this study is to provide a more integrative approach to air travel behavior-particularly deliberate reduction of flying-by combining individual, social and political factors that can potentially instigate a process to reduce or quit flying, and the interactions between those.

We explore both personal and political/societal incentives and barriers to air travel reduction, as perceived by individuals who reduce flying because of climate change and by individuals who do not reduce air travel. Moreover, we map out the typical phases and components of the process of reducing flying. We analyze this phenomenon through the lens of transformation to sustainability, thus providing a novel approach to framing individual air travel behavior in a political and societal context. Ultimately, we seek to contribute to knowledge relevant for policy development aiming at reducing air travel.

\section{Theoretical Framework}

The concept transformations to sustainability is increasingly used in research and policy as a metaphor for fundamental, systemic change to mitigate human impact on nature [60]. Transformations are often described as involving entire societies or social-ecological systems at multiple scales. However, transformation of human behavior is also an essential part of transformations to sustainability [9]. Individuals may contribute to large-scale transformation by both changing behavior and by influencing structures and systems [61].

The Three Spheres of Transformation framework [9,62], developed by Karen O'Brien and Linda Sygna, integrates different branches of research on transformations, highlighting the need for a comprehensive view on personal, institutional, societal and technological transformations as a response to climate change. O'Brien and Sygna argue that the most powerful transformations take place across three embedded and interacting spheres (Figure 1).

The practical sphere is the core, where the goals to meet climate change are located and measurable effects can be seen-for example, behavioral and technical responses. In the case of air travel, this could, e.g., be substantial reduction of flights and technological development that together lead to mitigated emissions. The political sphere entails the systems and structures "that create the conditions for transformations in the practical sphere" [9], including economic, political, legal, social and cultural systems. It is here that policy instruments such as taxes and regulations can be set up, and social norms and movements play out. The personal sphere is where individual and collective beliefs, values and worldviews can be transformed. Changes here can lead to new and different action logics, ways of interacting with the world, new discourses and paradigms that can change dominant systems and influence what solutions are prioritized in the other spheres. 


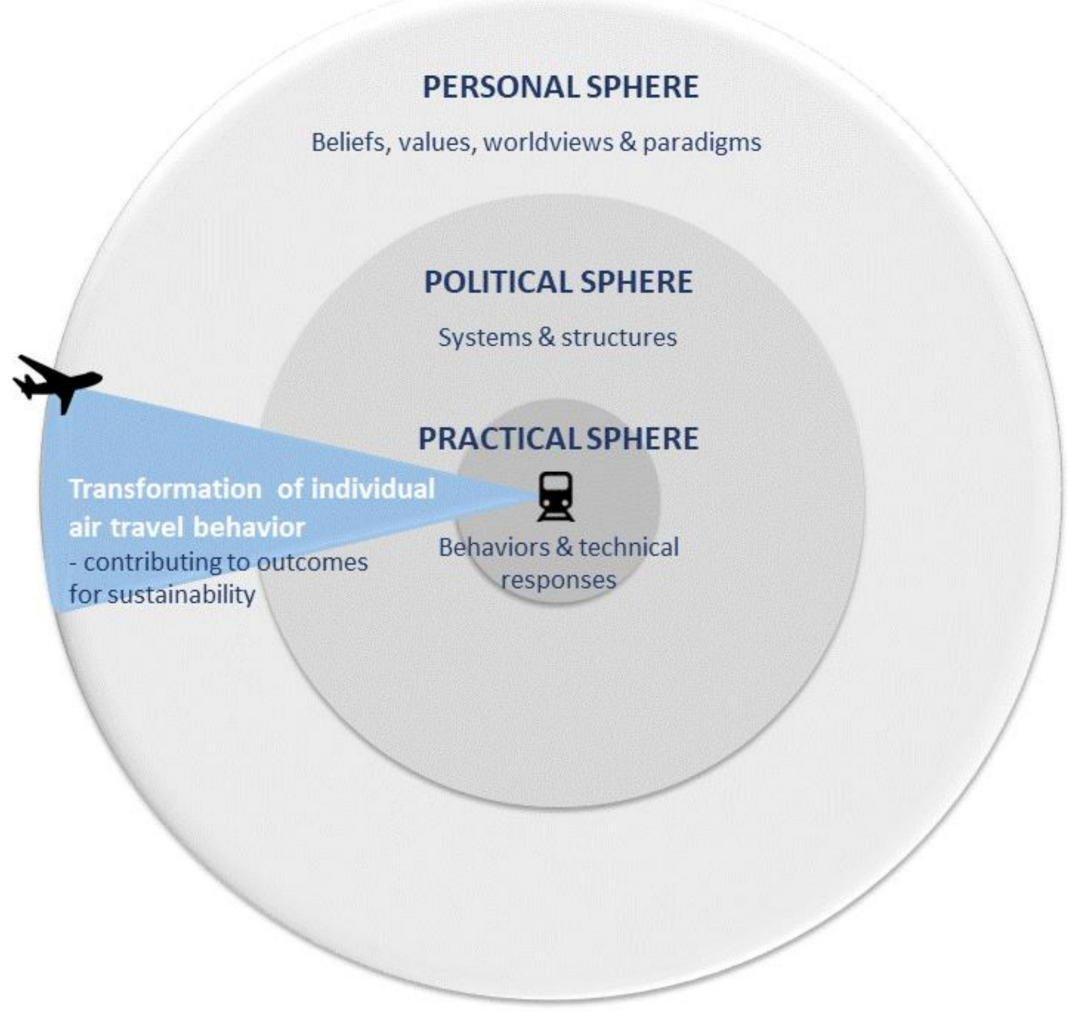

Figure 1. Three Spheres of Transformation, adopted from O'Brien and Sygna [9]. According to this framework, societal sustainability transformations in response to climate change take place across three interacting practical, political and personal spheres. "Transformation of individual air travel behavior" is added by the authors. Originally, the blue wedge illustrates "outcomes for sustainability" in general.

In this study, we use the spheres to investigate incentives (defined as factors driving the process of reducing flying) and barriers (defined as factors counteracting the change) to individual reduction of air travel. By mapping incentives and barriers in the personal and political spheres, we show how individual air travel behavior depends on beliefs, values, and worldviews (e.g., the perceptions of personal responsibility and emotions connected to climate change) as well as on political and social systems and structures (e.g., ticket prices and lack of alternative travel modes).

We apply the concept of tipping points in social and social-ecological systems (linked systems of people and nature) as a lens to understand transformation in the personal sphere [63]. While transformations can be slow and gradual, tipping points refer to more abrupt shifts. A social tipping point has been defined as a point at which small quantitative changes trigger a nonlinear change in the social component of the system, driven by a self-reinforcing positive feedback mechanism [64]. The change can be caused by slow variables eroding the threshold and fast variables pushing the shift. In this study, a personal tipping point refers to a non-linear shift in individual mindset and behavior.

\section{Materials and Methods}

The empirical basis for this study is qualitative, semistructured interviews with a phenomenological approach, meaning that we aim to understand air travel reduction based on the informants' own perception of their world [65]. This is a suitable method to achieve an in-depth understanding of a social phenomenon through a rich and nuanced account, i.e., a "thick description" [66]. The interviews were carried out in the fall 2017 and early 2018, mainly before the intense media debate on air traveling. 
Initially, both peer-reviewed articles and non-peer-reviewed reports from Swedish authorities were studied to gather background knowledge about air travel behavior, the impacts of aviation on climate and Swedish travelers' contribution. General media reporting on the topic was followed closely during the study period. Continuous observation of the discussions in the Facebook groups where most participants were recruited provided a broader contextual understanding.

\subsection{Recruitment of Interviewees}

Participants were purposively sampled [66], mainly via advertisements in the Facebook groups "Train vacation" (https:/www.facebook.com/groups/tagsemester/) [67], "I don't fly—for the sake of the climate" (www.facebook.com/groups/flygerinte/) [68] and "We who like travelling" (www.facebook. com/groups/visomgillarattresa/) [69]. Overall inclusion criteria were to be over 18 years of age and a Swedish resident. Thirty-seven individuals were initially interested to participate and provided a brief written description of themselves and their travel habits. Based on this, a maximum variation sample [70] considering, e.g., age, gender and occupation, was delineated. In total, 26 people were included in the study (Table 1). As our focus lay in behavioral change, it was mostly people who had reduced or quit flying that were interviewed, whereas a small group of "non-reducers" was included to provide additional perspectives on barriers and possible incentives. In spite of the aim for maximum variation, almost all had higher education and were native Swedes.

Table 1. Characteristics of interviewees.

\begin{tabular}{|c|c|c|c|c|c|}
\hline Pseudonym & Age & Gender & Place of Residence & Occupation & Category \\
\hline Ida & 28 & $\mathrm{~F}$ & Town, South Sweden & Student & Quitter \\
\hline Stina & 38 & $\mathrm{~F}$ & Stockholm & Social worker & Quitter \\
\hline Jörgen & 50 & M & Town, middle Sweden & Tractor driver & Quitter \\
\hline Frank & 36 & M & Village, middle Sweden & Forester & Quitter \\
\hline Hans & 61 & M & Town, West Sweden & Sustainability consultant & Quitter \\
\hline Kerstin & 61 & $\mathrm{~F}$ & Town, middle Sweden & Healthcare officer (on sick leave) & Quitter \\
\hline David & 47 & M & Stockholm & Communications officer & Quitter \\
\hline John & 44 & M & Village, South Sweden & Musician & Quitter \\
\hline Barbro & 68 & $\mathrm{~F}$ & Town, West Sweden & Retired researcher & Quitter \\
\hline Jakob & 52 & M & Town, middle Sweden & City planner & Quitter \\
\hline Olof & 30 & M & Town, West Sweden & Political officer/politician & Reducer \\
\hline Johannes & 30 & M & Town, South Sweden & University official & Reducer \\
\hline Julia & 41 & $\mathrm{~F}$ & Stockholm & Energy consultant (self-employed) & Reducer \\
\hline Lotta & 32 & $\mathrm{~F}$ & Village, West Sweden & Social worker (on parental leave) & Reducer \\
\hline Sara & 45 & $\mathrm{~F}$ & Town, North Sweden & Project manager, engineer & Reducer \\
\hline Sixten & 41 & M & Stockholm & IT consultant & Reducer \\
\hline Max & 30 & M & Town, South Sweden & Web developer & Reducer \\
\hline Kristian & 44 & M & Stockholm & Media consultant (self-employed) & Reducer \\
\hline Malin & 55 & $\mathrm{~F}$ & Town, West Sweden & Journalist (self-employed) & Reducer \\
\hline Diana & 41 & $\mathrm{~F}$ & Stockholm & Teacher & Non-reducer \\
\hline Jan-Erik & 72 & M & Stockholm & Retired financial manager & Non-reducer \\
\hline Annelie & 42 & $\mathrm{~F}$ & Stockholm & Journalist, manager & Non-reducer \\
\hline Henrik & 42 & M & Stockholm & Purchaser of IT systems & Non-reducer \\
\hline Staffan & 32 & M & Stockholm & Researcher & Non-reducer \\
\hline Siv & 66 & $\mathrm{~F}$ & Village, middle Sweden & Retired occupational therapist & Non-reducer \\
\hline Niklas & 35 & M & Town, North Sweden & Pedagogue & Non-reducer \\
\hline
\end{tabular}

$\square$ Quitter: Have made a decision not to fly, or once every five years at the most, and this is reflected by few flights 2015-2017); $\square$ Reducer: Have made a decision to reduce air travelling and self-report to have reduced to various degrees, compared to the previous five years; $\square$ Non-reducer: Self-report to fly approximately as much as the previous five years).

\subsection{Data Collection and Analysis}

In-depth interviews were performed from October 2017 to February 2018. The interviews were held in Swedish, were audio-recorded and lasted between 47 and $95 \mathrm{~min}$. Sixteen were performed face-to-face, nine were video calls and one was a telephone interview (to allow participation of interviewees from across Sweden). 
Following a semistructured approach, separate interview guides were used for people who had reduced air travel and for those who had not, while probes and follow-up questions were adjusted to the individual narratives [66]. The interviewees started by describing their air travel habits freely. Those who had reduced flying were asked open-ended questions about why and how this change came about, and about challenges and incentives. Interviewees who had not mitigated air travel were asked corresponding questions about their travel choices, what they thought about reducing flying for climate reasons, and about barriers and possible incentives to a potential reduction. Perceptions of climate change and the connection to flying, as well as who is responsible for emissions from air travel, and possible ways to reduce them were discussed. A short web questionnaire was used to collect detailed data on the participants' flights during 2015-2017.

The interviewees were categorized into three groups; "quitters", "reducers" and "non-reducers" (Table 1) to allow investigation of different degrees of change. Note that some reducers still did fly a lot despite substantial reduction compared with previous years-the decision and tendency to reduce were decisive in the categorization, not the annual number of flights.

All interviews were transcribed verbatim. A qualitative thematic analysis was performed [71,72] using the software NVivo 11 (QSR International 2017). In a first step, a bottom-up, inductive approach was used to generate an extensive list of codes strongly linked to the data. In a second stage, central themes were identified through sorting and combining the codes into themes and subthemes in a more deductive manner, related to research questions and theory. For example, all factors acting as incentives or barriers were grouped as belonging to the personal or political spheres.

\section{Results}

\subsection{The Process of Reducing or Quitting Air Travel}

A thematic analysis of the interviews with the 19 reducers and quitters revealed five themes and a number of subthemes that characterize the phases and components of the process of reducing or quitting flying (Figure 2). For a comprehensive coding frame with representative quotes, see Supplementary Materials Table S1.

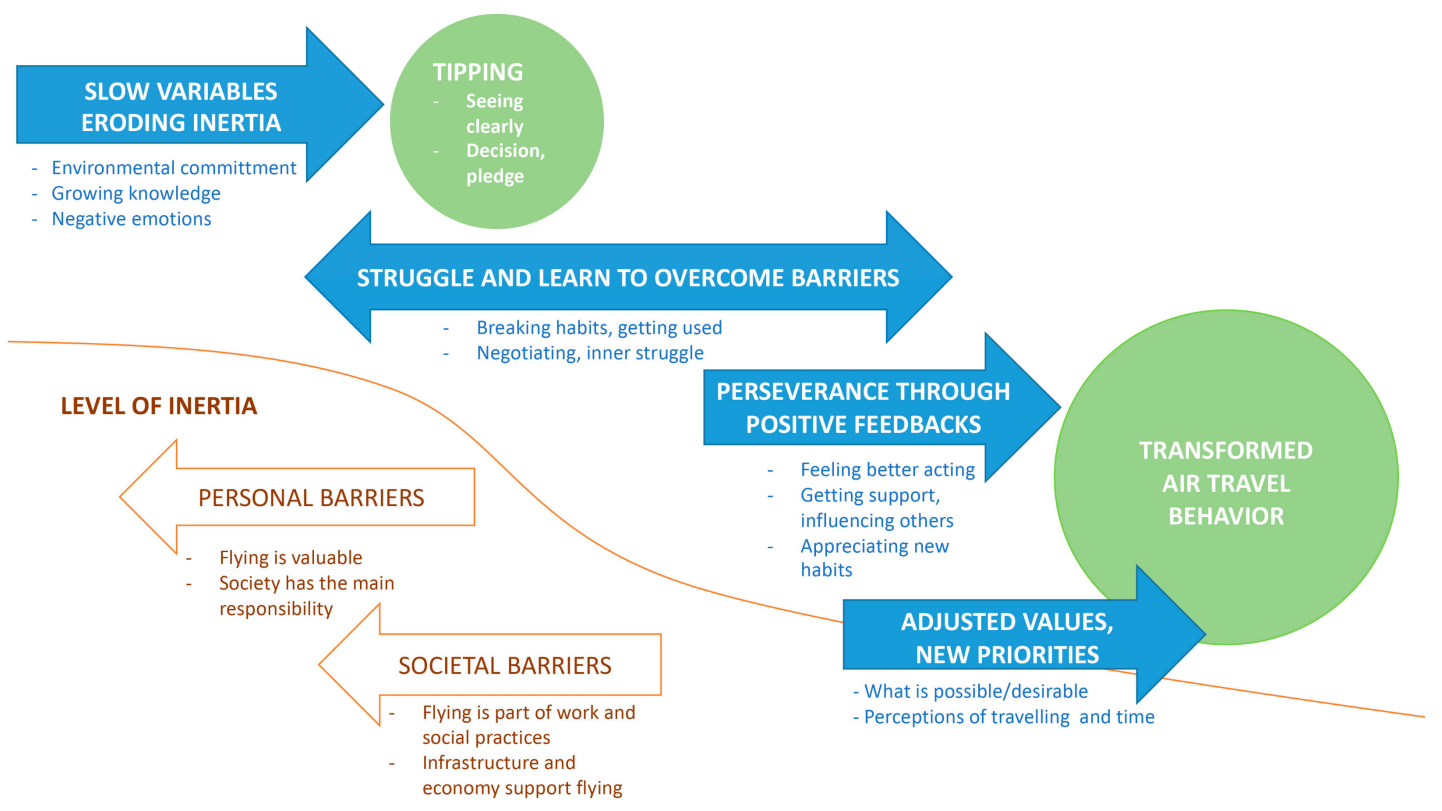

Figure 2. Phases and components of the transformation process. Blue arrows and green balls represent the different phases and components (themes emerging from the interviews) of the process of transforming air travel behavior, showing how this process typically plays out over time. Under each arrow, the consisting processes (subthemes) of each step theme are listed. Orange arrows show how the process is counteracted by various barriers. 


\subsubsection{Phase 1: Slow Variables Eroding Inertia}

Fifteen out of 19 quitters/reducers state that CC is the reason that they restrict flying. The remaining four also mention other significant causes, e.g., fear of flying. All quitters/reducers describe factors that influenced them during a longer period of time, and eventually led to a decision to reduce flying: At least 17 perceive themselves as environmentally committed, often since a young age, and almost all report a growing knowledge, via media but also through education. More than half are working with or have studied sustainability-related topics (often at college or university level).

A growing awareness of the connection between flying and CC results in rising negative emotions connected to flying. These emotions are often expressed in terms of cognitive dissonance as most continued to fly for some time, at odds with their values, before reducing:

"The decision had been cooking for quite a while [ ... ] when I got more and more insights into the consequences I started to feel a bit bad when I did it [ . . . ] The insights increase- the mental nausea increases." Hans, quitter

Some describe how they for some time tried to justify their flights. The musician John describes the common notion of flying being part of normalized practices, in his case work related, before he decided not to tour to places more distant than he can reach by train.

\subsubsection{Phase 2: Tipping Towards More Sustainable Habits}

More than half of the quitters/reducers speak about a point in time that can be described as a tipping point, leading to a decision to change behavior. Often a journey is the trigger. In Ida's case, a stay in Japan where she studied organic farming was decisive.

"The mask fell [ ... ] it became too embarrassing to continue to fly [... ]

It felt paradoxical to have emitted such an amount of greenhouse gases [ ... ]

when you are the kind of person who is engaged in these issues and should know better.

So it was probably there that my climate conscience had enough". Ida, quitter

In many cases, it is the growing cognitive dissonance that needs to be solved, like Ida, who felt an urge to live according to her values.

The cause for the shift is often multifactorial. Kerstin had for a long time been afraid of flying and simultaneously environmentally concerned. Finally, a positive experience with train traveling pushed her decision. David reached a tipping point after a cheap weekend flight; just upon returning he saw a documentary about CC and the psychological mechanisms of denial that "punctured his defense". He felt a need to act and measured his carbon footprint, which revealed the impact of his flights:

"It stood out, it was like 90 percent of my emissions. So I felt that if I'm going to do something, I have to cut it out. So then I decided that now it's enough." Ola, quitter

Measuring the own carbon footprint and seeing the impact of aviation was decisive for several (subtheme seeing clearly). This knowledge makes it difficult to return to an "innocent attitude".

\subsubsection{Phase 3: Struggling and Learning to Overcome Barriers}

The third phase, overlapping the first two, is one of struggle and learning. From this phase onwards, a difference emerges between reducers and quitters. The quitters make a more drastic commitment not to fly, while reducers are more pragmatic, sometimes having personal conditions (such as a need to fly for work) affecting their perceived possibilities for drastic reductions. 
Several informants describe the challenges of breaking habits:

"Somehow you want to go on travelling [by plane] but then you just have to decide that no, you won't. And there is a period when breaking these habits that is a bit messy." Frank, quitter

Before getting used to the new travel habits, some compare flying to an addiction—similar to the urge for a cigarette that arises in particular situations.

This phase is also a period of learning to travel in new ways, e.g., how to book an international train trip. Descriptions of an inner struggle, often causing considerable stress, are common. The reducers Julia and Olof, both working with international environmental issues, are constantly negotiating: are their achievements really worth the flights?

"I always feel like [ ... ] God, Olof, you are supposed to be an environmentalist! [ ... ] I hope my contribution will give a minus on some other carbon account." Olof, reducer

Similarly, some quitters have made exceptions when a journey was perceived as particularly important.

\subsubsection{Phase 4: Positive Feedbacks}

Particularly quitters describe satisfaction with their pledges. A sense of agency and a notion of "feeling better acting" are recurring. Reducing flying is a way to do something concrete, decreasing the individual carbon footprint substantially. Some find strength and hope in this action. The majority also describe how they start to appreciate their new habits, like Sara and Johannes, who have reduced flying because of climate anxiety but also like the slower pace of traveling by train:

"Now that I have done it for a year, really been fighting to get rid of as many flights as possible [ ... ] I have had time to travel a lot by train and noticed how much I like it." Johannes, reducer

Another subtheme is of social character; finding support and influencing others. Many quitters/reducers express feelings of being different and alone, as others perceive their decision as strange or even ridiculous. Finding supportive contexts such as Facebook groups acts as a positive feedback to stick to the decision. Several express a drive to influence others in a more sustainable direction by acting as good examples showing that a good, flight-free life is possible. Sometimes it pays off, making the decision worth pursuing.

\subsubsection{Phase 5: Developing New Priorities}

Reducing flying is perceived as a way to live more in accordance with held values. However, adjustments of priorities and worldviews do appear. The choice to fly less impacts the perception of what is possible or reachable. Hans describes it as "closing the hatch" to the possibilities offered by flying. Like several others, he does not see this as a sacrifice, because also his notion of what is desirable has changed. Now that he has not flown for a decade, marketing of cheap flights gives him nausea instead of an urge to fly.

Some claim that a less accessible world makes traveling (mainly by train) more adventurous, and they appreciate the journey as a goal in itself. Traveling at a slower and more leisurely pace is viewed as part of a less stressful life. Several interviewees question the motivations for long travels and call for reflection on what is important in life.

"Another kind of thinking is needed. Maybe you should look where the happiness is? Is it really in Malta? Is it in Hurghada?" Jörgen, quitter 


\subsection{Incentives and Barriers to Air Travel Reduction}

The results in this section are based on interviews with all 26 participants, including the non-reducers. As shown in Figure 3, almost all incentives to reduce flying can be placed in the personal sphere, while barriers are abundant both in personal and political spheres. A comprehensive coding structure can be found in Supplementary Materials (Tables S1 and S2) and descriptions of each factor in Supplementary Materials Table S2.

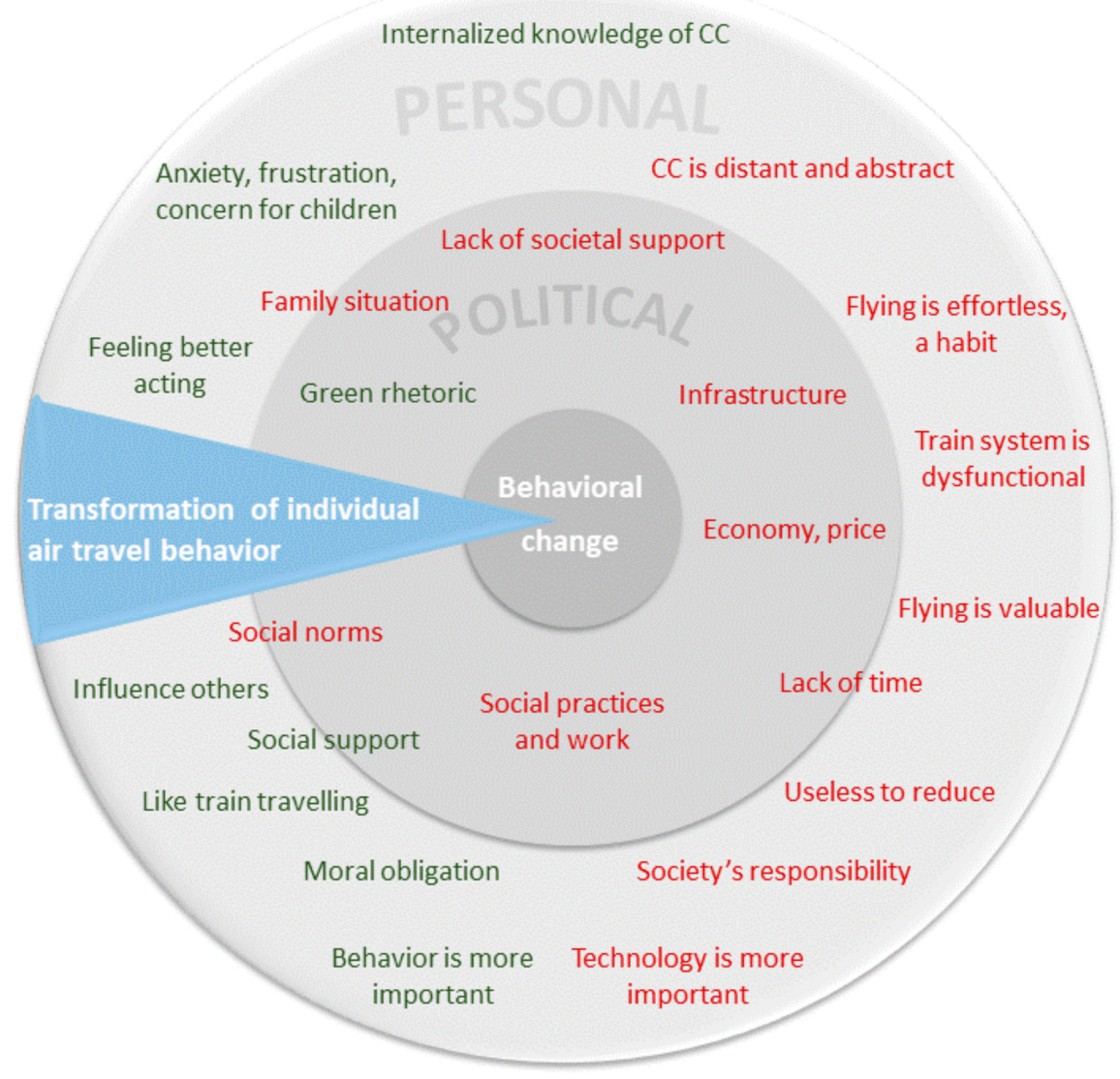

Figure 3. Incentives and barriers in personal and political spheres. Using the Three Spheres of Transformation adopted from O'Brien and Sygna [9] we map out the identified incentives (green) and barriers (red) to air travel reduction in the personal and political spheres. The personal sphere includes individual and collective beliefs, values and worldviews. The political sphere entails economic, political, legal, social and cultural systems. The practical sphere is the core-where the behavioral change takes place.

\subsubsection{Emotional Internalization of Climate Change}

The main reasons to restrict flying are knowledge about CC and its connection to aviation, and the associated emotional distress. Almost all quitters/reducers express deep concern, from "it doesn't feel good" to "cruel anxiety" and "panic". They paint a dark picture of the future: global warming will make parts of the world inhabitable, and food production will decrease. This will cause starvation, mass-migration, political tension and war. The impacts on humans are more prominent in their narratives than environmental impact. Closely connected to this concern about people is a sense of guilt and injustice—-the already vulnerable will be the hardest hit. 
In the non-reducer group, the sense of urgency varies. Some are well informed about CC, while others have fuzzy perceptions and refer to it as something happening in the Arctic, or that might be caused by natural cycles. While most are concerned with sustainability issues, some simultaneously express that rising temperatures may not be so serious, at least not in Sweden. Annelie, who is well informed, is herself puzzled why she is not changing behavior and suspects that it is because she does not feel threatened. She describes a notion of parallel realities seen in several interviews with non-reducers:

"You can be horrified by the reports showing how bad it is and how soon we must change everything to save something. And on the other hand, life just rolls on. Like if these reports almost live in some parallel universe." Annelie, non-reducer

In contrast to this perception of CC as something abstract and distant, the reducers/quitters have a more internalized notion of it. For them, the accumulating knowledge of CC has "been digested" or "taken into the body".

"You can't go around being depressed all the time [ ... ] then you wouldn't be able to live. But it's there, in the back of the head, all the time." John, quitter

Several speak of CC as something that will directly affect themselves, or at least their children. A few interviewees have internalized knowledge and concern to the point that they are concretely preparing for a bleak future, like the engineer Sara, who has bought a small farm to grow food for her children. Strong concern for the future of the children is frequently mentioned as an important incentive:

Since I got a child it became even more apparent. I almost panic thinking of how [ ... ] will she manage in the world if it goes on like this? Will she even have reasonable chances to get a good life? [ ... ] It's causing incredibly much anxiety thinking of how little you can do yourself." Stina, quitter

\subsubsection{Political Versus Individual Responsibility}

Virtually all hold the opinion that the state and politicians bear the heaviest responsibility for reducing emissions. Comments like "I'm really fed up with the idea that everything is up to the individuals" are common also among those who do change behavior.

Given that it is cheap and easy to fly, that it is the norm and part of practices, most interviewees think that people cannot be expected to reduce flying without economical or regulatory incentives. The non-reducer Staffan is outspokenly negative to individual reduction:

"If it's a societal problem, it has to be regulated on a societal level. It can't be up to ordinary people to decide this. So that's a bit the reason, I guess, why I don't [reduce]."

Reflecting on individuals who reduce flying, he expresses pity:

"I think it shouldn't punish them [ ... ] As a kind of protest, I would continue to fly, if it's the cheapest alternative, to show that it [... ] has to be regulated."

There is a general agreement that individual reductions have little effect in terms of emissions. However, many quitters/reducers hope that individuals through their acts can influence others. Even if their behavior has no concrete effect, they feel a moral obligation to act.

"You can't just shrug your shoulders and go on doing wrong. How can you live with yourself then? And then I think, if more people actually do something it will influence others." Stina, quitter 


\subsubsection{Lack of Support from Society}

The interviewees describe an almost complete lack of support from the political sphere to reduce flying. Many quitters/reducers feel that society is even working against them and that they are viewed as troublesome or naïve.

"There is nothing else than a kind of stupid 'I will do the right thing!' And then you do the right thing, but you are just disadvantaged, because it takes more time, it's more expensive and more hassle. There is no real benefit in acting like I do." Frank, quitter

Economy and time are perceived to steer the actions of most people, companies and society as a whole-a structural lock-in. However, frustration with political inaction may work as an incentive: if politicians and the state are doing nothing, and it is difficult to change society, the only remaining solution is to change yourself.

"There is no political will. We go on as long as we can, and then it goes to hell [ ... ] It's a big frustration. Yes. And all I can do is to at least live somewhat decently. It's not enough, I understand that, but I continue anyway." Barbro, quitter

\subsubsection{The value of flying}

One of the most important barriers to reducing flying is that it is valuable-in many ways. Particularly the non-reducers emphasize that air travel is important for learning about the world, to get sun during the dark winter and get away from everyday life and responsibilities.

Practical aspects are also important. Even if some dislike the feeling of being squeezed into a plane or spending time at airports, flying is described as effortless: fast, cheap and convenient. Alternative traveling - primarily by train-is perceived as dysfunctional, expensive and complicated. Some of the non-reducers had never considered the possibility to avoid air travel outside the Nordic countries. Thus, the lack of proper train infrastructures creates system lock-ins for reducing air travel.

While non-reducers describe it as a big sacrifice to restrict flying, quitters often mention that it is not-at least not compared to the environmental drawbacks of flying. Many perceive that the enjoyment of traveling can be found closer to home, even if some miss the possibility to visit friends far away. This is an important issue for Max, a frequent flyer who recently started to reduce. Having an international working and social life, reducing is a big sacrifice.

"If it hadn't been one of the absolutely worst things I can do to [ ... ] the happiness in my life, I wouldn't have waited so long." Max, reducer

Non-reducers often speak about flying in terms of necessity. Flying is needed to pursue a career or to see friends and family. Interviewees who travel for work describe a difficult trade-off when considering other travel modes than flying - the extra time would be taken from family life.

Several describe difficulties in breaking free from structures in a society built on the presumption that flying is normal and part of a number of practices. Frequent flyers depict it as "taking the subway" or "brushing teeth" - an integral part of their lifestyle. Retired Jan-Erik says that for pensioners with money and time, traveling is the "natural" thing to do-"everybody else does it". Both for leisure and work, traveling has become synonymous with flying.

\section{Discussion}

While earlier research has shown that climate concern is not enough for most people to reduce air traveling [27,42], this study deepens the insights in the cognitive and emotional involvement for those who do. Thus, we argue that knowledge of CC is an important factor (which is also confirmed by a survey study performed in Sweden in 2019 [56]) although this may seem to be in conflict with the well-established knowledge-action gap. This gap, however, can be bridged by internalization of 
the knowledge. This is supported by the finding that quitters/reducers have connected knowledge of $\mathrm{CC}$ to emotions and personal life-contrasting to the more common perception of $\mathrm{CC}$ as something abstract and distant [38].

More research is needed to clarify how this internalization occurs, but for many interviewees, a long-standing environmental commitment led to growing knowledge and negative emotions connected to flying - which in turn led to a personal tipping point triggering behavioral change. Measuring one's own carbon footprint and realizing air travel's large part may contribute to the internalization.

We show that emotions also play a substantive role in inducing climate action. The incentivizing emotions are mainly negative: anxiety for the future, guilt and concern for the children. This seems to contradict some earlier research suggesting that negative emotions passivize and that positive visions trigger action $[38,73]$. However, we show that positive emotions often appear after the behavioral change, acting as reinforcing feedbacks.

The importance of internalized knowledge shown in this study highlights the need for improved climate communication and education $[32,74,75]$, and to adjust it to different target audiences. On one hand, it is actually doomsday scenarios that loom in the back of the heads of quitters/reducers and that trigger change. On the other hand, the non-reducers may block out the same messages and keep them disconnected from their personal lives [38,39]. For those, attractive alternatives and economic incentives appear as more efficient.

Our study confirms several earlier findings: flying is the norm and part of many social practices and therefore hard to separate from, for example, vacation and work [46]. Our interviews reveal little support-but many barriers-to reduce flying in the political sphere and society at large. The observation that reducers feel a moral obligation to act is also confirmed [42]. While quitters solve cognitive dissonance by cutting out flying from their lives, non-reducers choose the more common solution of finding various justifications for their flights [28].

Reducing flying or not depends on an individual set of incentives and barriers (Figure 4). We have shown that a number of structures in society make it hard to limit flying even for those who have strong personal incentives to do so. Hence, we suggest that targeting interventions at the political sphere may propel transformation of air travel behavior.

Our analysis through the Three Spheres of Transformation contributes an integrative perspective, taking into account both personal and political spheres and the interactions between these. The interviewees point out a number of potential political incentives that could influence the personal sphere and contribute to a transformation of air travel behavior. More expensive flights and various regulations are seen as the most powerful, although high prices are perceived as unfair, making traveling affordable only for the rich. Therefore, attractive and priceworthy alternatives to flying are called for, such as better and cheaper international train connections, more convenient booking systems and more night trains. The proposed flight tax in Sweden was generally regarded as far too low but could be improved to be more efficient [26]. Other potential policy tools could be to make it compulsory for airline companies to disclose information about their emissions and enforce rules to force them to pay for their emissions [63].

The right policy interventions targeting the interacting spheres could be mutually reinforcing and spark a positive chain reaction contributing to a more sustainable travel system. For example, compulsory climate education in schools (political sphere) could influence individuals' environmental awareness and values (personal sphere), which might reduce the willingness to pay for air travel $[25,26]$. This, in turn, could increase the pressure on the political sphere to provide cleaner solutions and, for example, stimulate the development of a more well-functioning international train system (political/practical spheres), which would probably attract more people to sustainable traveling. This kind of cascading effect could potentially instigate a social tipping point for the air travel system-even if there is an ongoing debate of the nature of such tipping points $[63,76]$. 


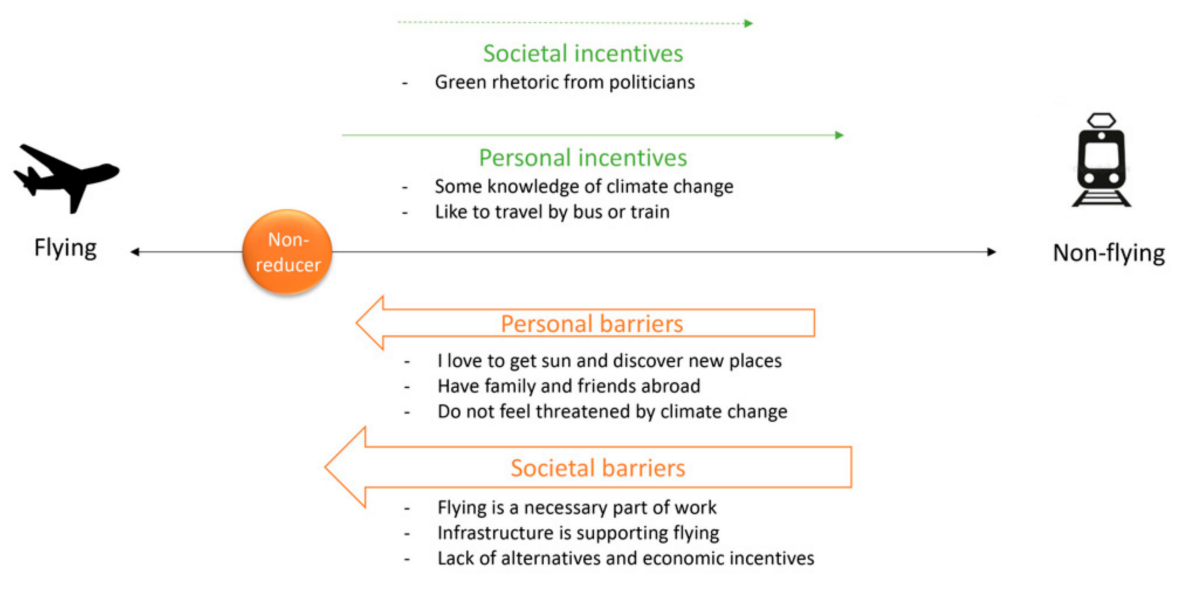

(a) Non-reducer

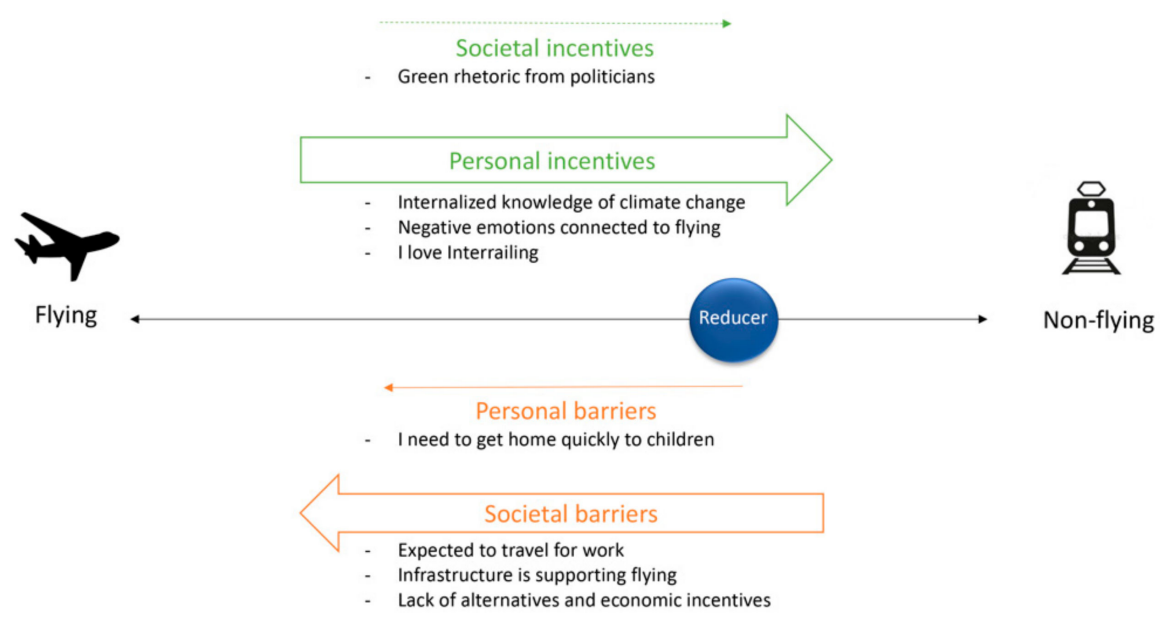

(b) Reducer

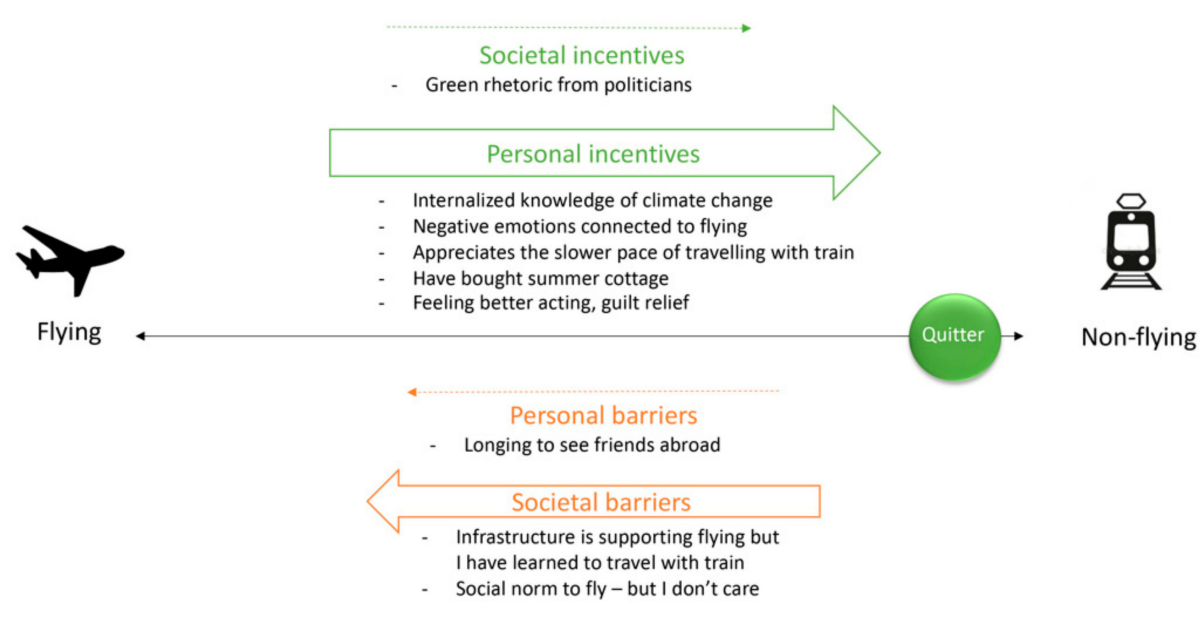

(c) Quitter

Figure 4. Interacting incentives and barriers in different categories of interviewees. The figure shows how different incentives and barriers interact. For a non-reducer (a), both personal and societal barriers are much stronger (represented by thicker arrows) than the incentives to reduce flying. For a typical reducer $(\mathbf{b})$, the personal incentives to reduce are strong, but particularly the societal barriers are difficult to overcome. The quitter (c) has overcome most of the barriers (or they were not so high in the first place) and thus succeeds to stop flying. 
The quitters/reducers seemed to genuinely appreciate their new slower and more conscious travel habits and to discover the beauty of the closer surroundings. This sense of increased well-being resonates with the theory of "alternative hedonism" suggesting that some people turn to a more environmentally friendly lifestyle as consumerism has become compromised by stress, congestion, pollution and ill-health-but also because of the intrinsic pleasures more sustainable choices afford [77]. Moreover, our study suggests that making a concrete change provides a possibility to break out from a society one is frustrated with, a relief from collective climate guilt. Accordingly, the highest levels of anxiety were expressed by some interviewees highly motivated to reduce but stuck in a professional situation that requires flying.

Our interviews provide a rich narrative of reducing flying as going against the grain, breaking norms and fighting structures and systems-while ultimately also providing positive experiences. Based on observations of the Facebook groups and by following the media discussion, we consider the quitters/reducers fairly representative for Swedes who quit or reduce flying for climate reasons. This is supported by the observation that the last interviews with quitters/reducers did not provide many new insights. We make no claims that the small sample of non-reducers is representative of Swedish travelers overall. Still, they provided useful insights about barriers and potential incentives for air travel reduction.

\section{Concluding Remarks}

Rational knowledge about the threats of CC is essential but often not powerful enough to make people reduce flying. An emotional internalization is imperative. However, not even a conviction that reducing flying is the right thing to do is sufficient to achieve drastic behavioral change for people who are too entangled in the knot of habits, norms and structures promoting air travel. To achieve behavioral change at a larger scale-including those without strong personal incentives-more support is needed from the political sphere. This could be a combination of improving travel alternatives, e.g., better train infrastructure and economic and regulatory policy instruments promoting cleaner alternatives, as well as improved climate communication and education to change social norms.

New perceptions of what kind of traveling is desirable could be an important driver for a broader transformation of travel behavior. Here, quitters/reducers may play a role as moral entrepreneurs [78] working to change norms and values. Particularly reducers/quitters with influential positions or media platforms can spark cascading effects, as demonstrated in a vivid debate about flying in Swedish media in 2018- that might have contributed to the decline of air passengers at Swedish airports in 2019 [58]. Other potential explanations are the introduction of the flight tax in 2018, the heat and wildfires during the same summer and climate activist Greta Thunberg's school strike that sparked a global movement. All these factors might have increased both knowledge of CC and emotional involvement. Currently, the Swedish word for "flight shame" and the social media movement "Flight Free 2020" has spread internationally $[57,79]$. Our interviewees may thus be seen as front runners in a rising global movement.

Supplementary Materials: The following are available online at http://www.mdpi.com/2071-1050/12/5/1994/s1, S1: Coding structure for the process of change, Coding structure for incentives and barriers, and S2: Description of incentives and barriers.

Author Contributions: Conceptualization, L.J. and A.K.B.; data curation and analysis, L.J.; methodology, L.J. and M.G.; supervision, J.Å., M.G. and A.K.B.; writing—original draft, L.J.; writing—review and editing, L.J., J.A.,, M.G. and A.K.B. All authors have read and agreed to the published version of the manuscript.

Funding: This research was conducted as a master's thesis as part of the MSc program Social-Ecological Resilience for Sustainable Development at Stockholm Resilience Centre (SRC), Stockholm University. SRC funded the fieldwork (train travels, recording equipment, software for data analysis). Stockholm University Library funded the APC.

Acknowledgments: We thank the interviewees for sharing their thoughts, experiences and emotions, which were indispensable for this study. Diego Galafassi provided valuable input to an earlier version of the manuscript. We also thank three anonymous reviewers for insightful comments that helped to substantially improve the manuscript. 
Conflicts of Interest: The authors declare no conflict of interest.

\section{References}

1. UNFCCC. Paris Agreement; United Nations Framework Convention on Climate Change. Available online: https:/unfccc.int/process-and-meetings/the-paris-agreement/the-paris-agreement/ (accessed on 27 May 2018).

2. Masson-Delmotte, V.; Zhai, P.; Pörtner, H.O.; Roberts, D.; Skea, J.; Shukla, P.R.; Pirani, A.; Moufouma-Okia, W.; Péan, C.; Pidcock, R.; et al. Global warming of $1.5^{\circ} \mathrm{C}$. An IPCC Special Report on the impacts of global warming of $1.5^{\circ} \mathrm{C}$ above pre-industrial levels and related global greenhouse gas emission pathways, in the context of strengthening the global response to the threat of climate change, sustainable development, and efforts to eradicate poverty. Available online: https://ipcc.ch/sr15/ (accessed on 3 October 2019).

3. Pörtner, H.-O.; Roberts, D.C.; Masson-Delmotte, V.; Zhai, P.; Tignor, M.; Poloczanska, E.; Mintenbeck, K.; Nicolai, M.; Okem, A.; Petzold, J.; et al. IPCC Special Report on the Ocean and Cryosphere in a Changing Climate. Available online: https://ipcc.ch/srocc/ (accessed on 3 October 2019).

4. Anderson, K. Duality in climate science. Nat. Geosci. 2015, 8, 898. [CrossRef]

5. Rockström, J.; Gaffney, O.; Rogelj, J.; Meinshausen, M.; Nakicenovic, N.; Schellnhuber, H.J. A Roadmap for Rapid Decarbonization. Science 2017, 355, 1269-1271. [CrossRef] [PubMed]

6. Pelling, M.; O’Brien, K.; Matyas, D. Adaptation and transformation. Clim. Chang. 2015, 133, $113-127$. [CrossRef]

7. Göpel, M. The Great Mindshift: How a New Economic Paradigm and Sustainability Transformations go Hand in Hand; Wuppertal Institute Springer Open: Berlin/Heidelberg, Germany, 2016; ISBN 978-3-319-43766-8. [CrossRef]

8. Fazey, I.; Moug, P.; Allen, S.; Beckmann, K.; Blackwood, D.; Bonaventura, M.; Burnett, K.; Danson, M.; Falconer, R.; Gagnon, A.S.; et al. Transformation in a changing climate: A research agenda. Clim. Dev. 2018, 10, 197-217. [CrossRef]

9. O'Brien, K.; Sygna, L. Responding to Climate Change: The Three Spheres of Transformation. In Proceedings of the Transformation in a Changing Climate, 19-21 June 2013; University of Oslo: Oslo, Norway, 2013; pp. 16-23, ISBN 978-82-570-2000-2.

10. Lee, D.S.; Fahey, D.W.; Forster, P.M.; Newton, P.J.; Wit, R.C.N.; Lim, L.L.; Owen, B.; Sausen, R. Aviation and global climate change in the 21st century. Atmos. Environ. 2009, 43, 3520-3537. [CrossRef]

11. Azar, C.; Johansson, D.J.A. Valuing the non-CO2 climate impacts of aviation. Clim. Chang. 2012, 111, 559-579. [CrossRef]

12. Kärcher, B. Formation and radiative forcing of contrail cirrus. Nat. Commun. 2018, 9, 1-17. [CrossRef]

13. Gössling, S.; Peeters, P. ‘It Does Not Harm the Environment!' An Analysis of Industry Discourses on Tourism, Air Travel and the Environment. J. Sustain. Tour. 2007, 15, 402-417. [CrossRef]

14. Sullivan, A. To Fly or not to Fly? The Environmental Cost of Air Travel. Available online: https://www.dw. com/en/to-fly-or-not-to-fly-the-environmental-cost-of-air-travel/a-42090155 (accessed on 13 February 2020).

15. Kamb, A.; Larsson, J.; Nässén, J.; Åkerman, J. Klimatpåverkan Från Svenska Befolkningens Internationella Flygresor; FTR-Rapport nr 2016:02; Chalmers Tekniska Högskola: Göteborg, Sweden, 2016.

16. Åkerman, J. Climate impact of international travel by Swedish residents. J. Transp. Geogr. 2012. [CrossRef]

17. Airbus. Global Market Forecast. Growing Horizons 2017-2036; Airbus: Blagnac, France, 2017.

18. Peeters, P.; Higham, J.; Kutzner, D.; Cohen, S.; Gössling, S. Are technology myths stalling aviation climate policy? Transp. Res. Part D Transp. Environ. 2016, 44, 30-42. [CrossRef]

19. Åkerman, J.; Larsson, J.; Elofsson, A. Svenska Handlingsalternativ För att Minska Flygets Klimatpåverkan; Kungliga Tekniska Högskolan: Stockholm, Sweden, 2016.

20. Larsson, J. Hållbara Konsumtionsmönster. Analyser av Maten, Flyget Och Den Totala Konsumtionens Klimatpåverkan Idag Och 2050; Naturvårdsverket: Stockholm, Sweden, 2015.

21. Wynes, S.; Nicholas, K.A. The climate mitigation gap: Education and government recommendations miss the most effective individual actions. Environ. Res. Lett. 2017, 12, 074024. [CrossRef]

22. UNDP. Human Development Report 2007/2008 Fighting Climate Change: Human Solidarity in a Divided World; UNDP: New York, NY, USA, 2007; ISBN 9780230547049. 
23. Nykvist, B.; Persson, Å.; Moberg, F.; Persson, L.; Cornell, S.; Rockström, J. National Environmental Performance on Planetary Boundaries National Environmental; Naturvårdsverket: Stockholm, Sweden, 2013; ISBN 9789162065768.

24. Neill, D.W.O.; Fanning, A.L.; Lamb, W.F.; Steinberger, J.K. A good life for all within planetary boundaries. Nat. Sustain. 2018, 1, 88. [CrossRef]

25. Yakita, A.; Yamauchi, H. Environmental awareness and environmental R \& D spillovers in differentiated duopoly. Res. Econ. 2011, 65, 137-143. [CrossRef]

26. Hsu, C.C.; Lee, J.Y.; Wang, L.F.S. Consumers awareness and environmental policy in differentiated mixed oligopoly. Int. Rev. Econ. Financ. 2017, 51, 444-454. [CrossRef]

27. Higham, J.; Reis, A.; Cohen, S.A. Australian climate concern and the 'attitude-behaviour gap'. Curr. Issues Tour. 2016, 19, 338-354. [CrossRef]

28. McDonald, S.; Oates, C.J.; Thyne, M.; Timmis, A.J.; Carlile, C. Flying in the face of environmental concern: Why green consumers continue to fly. J. Mark. Manag. 2015, 31, 1503-1528. [CrossRef]

29. Cohen, S.A.; Higham, J.E.S. Eyes wide shut UK consumer perceptions on aviation climate impacts and travel decisions to New Zealand. Curr. Issues Tour. 2011, 14, 323-335. [CrossRef]

30. Stern, P.C. New Environmental Theories: Toward a Coherent Theory of Environmentally Significant Behavior. J. Soc. Issues 2000, 56, 407-424. [CrossRef]

31. Stern, P.C. Information, Incentives, and Proenvironmental Consumer Behavior. J. Consum. Policy 1999, 22, 461-478. [CrossRef]

32. Moser, S.C.; Dilling, L. Communicating Climate Change: Closing the Science-Action Gap. In The Oxford Handbook of Climate Change and Society; Dryzek, J., Norgard, R.B., Schlosberg, D., Eds.; Oxford University Press: Oxford, UK, 2011; pp. 161-174.

33. Kollmuss, A.; Agyeman, J. Mind the Gap: Why do people act environmentally and what are the barriers to pro-environmental behavior? Environ. Educ. Res. 2002, 8, 239-260. [CrossRef]

34. Negev, M.; Sagy, G.; Garb, Y.; Salzberg, A.; Tal, A. Evaluating the environmental literacy of Israeli elementary and high school students. J. Environ. Educ. 2008, 39, 3-20. [CrossRef]

35. Juvan, E.; Dolnicar, S. The attitude-behaviour gap in sustainable tourism. Ann. Tour. Res. 2014, 48, 76-95. [CrossRef]

36. Gifford, R. The Dragons of Inaction: Psychological Barriers That Limit Climate Change Mitigation and Adaptation. Am. Psychol. 2011, 66, 290-302. [CrossRef] [PubMed]

37. Weber, E.U. What shapes perceptions of climate change? New research since 2010. Wiley Interdiscip. Rev. Clim. Chang. 2016, 7, 125-134. [CrossRef]

38. Stoknes, P.E. What We Think about When We Try not to Think about Global Warming: Toward a New Psychology of Climate Action; Chelsea Green Publishing: White River Junction, VT, USA, 2015.

39. Norgaard, K.M. Living in Denial: Climate Change, Emotions, and Everyday Life; MIT Press: Cambridge, MA, USA, 2011.

40. Shove, E. Beyond the ABC: Climate change policy and theories of social change. Environ. Plan. A 2010, 42, 1273-1285. [CrossRef]

41. Cohen, S.A.; Higham, J.E.S.; Reis, A.C. Sociological barriers to developing sustainable discretionary air travel behaviour. J. Sustain. Tour. 2013, 21, 982-998. [CrossRef]

42. Büchs, M. The role of values for voluntary reductions of holiday air travel. J. Sustain. Tour. 2016, 25, $234-250$. [CrossRef]

43. Kroesen, M. Exploring people's viewpoints on air travel and climate change: understanding inconsistencies. J. Sustain. Tour. 2013, 21, 271-290. [CrossRef]

44. Climate Change and Aviation: Issues, Challenges and Solutions; Gössling, S.; Upham, P. (Eds.) Earthscan: London, UK, 2009.

45. Cohen, S.A.; Higham, J.E.S.; Cavaliere, C.T. Binge flying. Behavioural addiction and climate change. Ann. Tour. Res. 2011, 25, 234-250. [CrossRef]

46. Randles, S.; Mander, S. Practice(s) and ratchet(s): A sociological examination of frequent flying. In Climate Change and Aviation: Issues, Challenges and Solutions; Gössling, S., Upham, P., Eds.; Earthscan: London, UK, 2009; pp. 245-271. 
47. Naturvårdsverket. Växthusgaser-konsumtionsbaserade utsläpp per person. Available online: https://www.naturvardsverket.se/Sa-mar-miljon/Statistik-A-O/Vaxthusgaser-konsumtionsbaseradeutslapp-per-person/ (accessed on 16 February 2020).

48. Lee, T.M.; Markowitz, E.M.; Howe, P.D.; Ko, C.-Y.; Leiserowitz, A.A. Predictors of public climate change awareness and risk perception around the world. Nat. Clim. Chang. 2015. [CrossRef]

49. Gössling, S.; Haglund, L.; Kallgren, H.; Revahl, M.; Hultman, J. Swedish air travellers and voluntary carbon offsets towards the co creation of environmental value. Curr. Issues Tour. 2009, 12, 1-19. [CrossRef]

50. Martinsson, J.; Andersson, U. Svenska Trender 1986-2017; Martinsson, J., Andersson, U., Eds.; SOM Institute: Göteborg, Sweden, 2018.

51. Kamb, A.; Larsson, J. Klimatpåverkan från svenska befolkningens flygresor 1990-2017. Available online: https://research.chalmers.se/en/publication/506796 (accessed on 15 February 2020).

52. Larsson, J.; Kamb, A.; Nässén, J.; Åkerman, J. Measuring greenhouse gas emissions from international air travel of a country's residents methodological development and application for Sweden. Environ. Impact Assess. Rev. 2018, 72, 137-144. [CrossRef]

53. Liljestrand, J. Jag är trött på att visa mina barn en döende värld. Available online: https://www.expressen.se/ kultur/jens-liljestrand/jag-ar-trott-pa-att-visa-mitt-barn-en-doende-varld/ (accessed on 14 January 2018).

54. Mjörnstedt Karlsten, J. Hur kunde jag inte veta detta. Available online: https://www.expressen.se/gt/ kronikorer/julia-mjornstedt-karlsten/hur-kunde-jag-inte-veta-detta/ (accessed on 15 January 2018).

55. Hadley Kamptz, I. Jag ser deras flygresor och min avund vet inga gränser. Available online: https://www. expressen.se/kultur/isobel-hadley-kamptz/jag-ser-deras-resor-och-min-avund-vet-inga-granser/ (accessed on 17 January 2018).

56. Wolrath-Söderberg, M.; Wormbs, N. Grounded-Beyond Flygskam; Fores: Stockholm, Sweden, 2019.

57. Mkono, M. Eco-anxiety and the flight shaming movement: Implications for tourism. J. Tour. Fut. 2019, 3. [CrossRef]

58. Transportstyrelsen. Available online: https://www.transportstyrelsen.se/sv/Nyhetsarkiv/flygresandetminskade-kraftigt-under-arets-forsta-kvartal/ (accessed on 14 April 2019).

59. Barr, S.; Prillwitz, J. A Smarter Choice? Exploring the Behaviour Change Agenda for Environmentally Sustainable Mobility. Environ. Plan. C Gov. Policy 2014, 32, 1-19. [CrossRef]

60. Feola, G. Societal transformation in response to global environmental change: A review of emerging concepts. Ambio 2015, 44, 376-390. [CrossRef]

61. O'Brien, K. Political agency: The key to tackling climate change. Science 2015, 350, 1170-1171. [CrossRef]

62. O'Brien, $\mathrm{K}$. Is the $1.5^{\circ} \mathrm{C}$ target possible? Exploring the three spheres of transformation. Curr. Opin. Environ. Sustain. 2018, 31, 153-160. [CrossRef]

63. Otto, I.M.; Donges, J.F.; Cremades, R.; Bhowmik, A.; Hewitt, R.J.; Lucht, W.; Rockström, J.; Allerberger, F.; McCaffrey, M.; Doe, S.S.P.; et al. Social tipping dynamics for stabilizing Earth's climate by 2050. Proc. Natl. Acad. Sci. USA 2020. [CrossRef]

64. Milkoreit, M.; Hodbod, J.; Baggio, J.; Benessaiah, K.; Donges, J.F.; Mathias, J.; Rocha, J.C.; Schoon, M. Defining tipping points for social-ecological systems scholarship-An interdisciplinary literature review. Environ. Res. Lett. 2018, 13, 033005. [CrossRef]

65. Kvale, S.; Brinkmann, S. Den Kvalitativa Forskningsintervjun, 3rd ed.; Studentlitteratur: Lund, Sweden, 2014.

66. Bryman, A. Social Research Methods; Oxford University Press: Oxford, UK, 2012.

67. Tågsemester. Available online: https://www.facebook.com/groups/tagsemester/ (accessed on 1 October 2017).

68. Jag flyger inte-för klimatets skull. Available online: www.facebook.com/groups/flygerinte/ (accessed on 29 September 2017).

69. Vi som gillar att resa. Available online: www.facebook.com/groups/Visomgillarattresa/ (accessed on 2 October 2017).

70. Teddlie, C.; Tashakkori, A. Foundations of Mixed Methods Research: Integrating Quantitative and Qualitative Approaches in the Social and Behavioral Sciences; SAGE Publishing: Thousand Oaks, CA, USA, 2009.

71. Braun, V.; Clarke, V. Using thematic analysis in psychology. Qual. Res. Psychol. 2006, 3, 77-101. [CrossRef]

72. Boyatzis, R.E. Transforming Qualitative Information: Thematic Analysis and Code Development; SAGE Publishing: Thousand Oaks, CA, USA, 1998. 
73. Bennett, E.M.; Solan, M.; Biggs, R.; McPhearson, T.; Norström, A.V.; Olsson, P.; Pereira, L.; Peterson, G.D.; Raudsepp-Hearne, C.; Biermann, F.; et al. Bright spots: Seeds of a good Anthropocene. Front. Ecol. Environ. 2016, 14, 441-448. [CrossRef]

74. Ojala, M. Hope in the Face of Climate Change: Associations with Environmental Engagement and Student Perceptions of Teachers Emotion Communication Style and Future Orientation. J. Environ. Educ. 2015. [CrossRef]

75. Plutzer, E.; Mccaffrey, M.; Hannah, A.L.; Rosenau, J.; Berbeco, M.; Reid, A.H. Climate confusion among U.S. teachers. Science 2016, 351, 664-665. [CrossRef] [PubMed]

76. Roberts, D. Social Tipping Points are the Only Hope for the Climate. Available online: https://www.vox.com/ energy-and-environment/2020/1/29/21083250/climate-change-social-tipping-points (accessed on 8 February 2020).

77. Soper, K. Alternative Hedonism, culture theoty and the role of aesthetic revisioning. Cult. Stud. 2008, 22, 567-587. [CrossRef]

78. Antadze, N.; McGowan, K.A. Moral entrepreneurship: Thinking and acting at the landscape level to foster sustainability transitions. Environ. Innov. Soc. Transit. 2017, 25, 1-13. [CrossRef]

79. Coffey, H. What is "flygskam"? Everything you need to know about the environmental movement that's sweeping Europe. Available online: https://www.independent.co.uk/travel/news-and-advice/flygskam-antiflying-flight-shaming-sweden-greta-thornberg-environment-air-travel-train-brag-a8945196.html (accessed on 8 February 2020).

(C) 2020 by the authors. Licensee MDPI, Basel, Switzerland. This article is an open access article distributed under the terms and conditions of the Creative Commons Attribution (CC BY) license (http://creativecommons.org/licenses/by/4.0/). 